\title{
Multivariate characterization and canonical interrelations for the productive performance of open pollinated corn genotypes
}

\author{
C. $^{\text {Troyjack }}{ }^{1}$, J.R. Pimentel ${ }^{1}$, I.R. Carvalho ${ }^{1}$, V.J. Szareski ${ }^{1}$, \\ G.T. Junior ${ }^{2}$, Í.T.P. Dubal ${ }^{1}$, G.H. Demari ${ }^{1}$, L.B.A. Jaques ${ }^{1}$, F. Kock ${ }^{1}$, \\ S.M. Delagostin ${ }^{1}$, F. Lautenchleger ${ }^{2}$, F.A. Villela ${ }^{1}$, T.Z. Aumonde ${ }^{1}$ and \\ T. Pedó ${ }^{1}$
}

${ }^{1}$ Universidade Federal de Pelotas, Capão do Leão, RS, Brasil
${ }^{2}$ Universidade Estadual Universidade Estadual do Centro-Oeste,
Guarapuava, PR, Brasil

Corresponding author: I.R. Carvalho

E-mail: carvalho.irc@gmail.com

Genet. Mol. Res. 18 (2): gmr18123

Received August 23, 2018

Accepted March 28, 2019

Published May 13, 2019

DOI http://dx.doi.org/10.4238/gmr18123

\begin{abstract}
Corn is considered one of the most important crops in the world agricultural scenario. In order to improve production, it is crucial to understand and quantify the genetic variation involved in the phenotypic manifestation of this species. We characterized corn genotypes using a multivariate approach and examined canonical interrelations between characters of agronomic importance. The study was carried out in the 2016/2017 crop year in the southernmost state of Brazil, in the northwest region of Rio Grande do Sul. The treatments were composed of six open-pollinated corn genotypes (PL 712, PL 725, PL 796, PL 804 and PL 861). The experimental design was a randomized block with four replications. Analysis of variance revealed a significant difference at $5 \%$ of probability by the $\mathrm{F}$ test for the attributes plant height, ear insertion height, stem diameter, ear length, number of seed rows per ear, number of seeds per row of ear, thousand seed weight, seed yield, percentage of germination, first germination count, emergency percentage and cold test. Genetic variability analysis showed genotype PL 712 to have superior seed productivity. The physiological quality of the seeds produced was variable among the genotypes, but it followed the trend of superiority for PL 712. Linear associations revealed a
\end{abstract}


tendency for tall stature plants to increase seed yield of open pollinated corn. The most polymorphic characters were plant height and ear insertion, response to cold test, and thousand seed weight. The productivity and seed quality trends that were observed will allow us to plan further research on open pollinated varieties to allow selection and development of superior genotypes for seed productivity and quality in the extreme south of Brazil.

Key words: Zea mays; Production of seeds; Byometric models; Univariate; Multivariate approach

\section{INTRODUCTION}

Corn (Zea mays) is a crop with great commercial application, originating from Mexico (Marchi, 2008). This cereal has significant economic, social and agricultural importance, since it is one of the main cultivated species in the world, with multiple purposes of use, including human and animal food, bioproducts and biofuels (Ferreira Júnior et al., 2014). This cereal stands out in Brazil with more than 96 million tons of grains produced in the 2016/2017 harvest in an area of 18 million hectares (Conab, 2017).

In this context, it is relevant to determine the performance of corn genotypes, in order to direct the management strategies to be used, so that there are no limiting abiotic or biotic factors throughout the production cycle. Consequently, understanding the genetic basis of the genotypes is essential for the adequate planning of the crop, being available more than 3,000 varieties of open pollinated and hybrid corn (Morris et al., 2003), including simple, modified, double and triple hybrids (Sangoi et al., 2006).

Under conditions that employ relatively unsophisticated growing technologies, maize hybrids may show inferior performance compared to open pollinated varieties (Pipolo, 2010). Open pollinated genotypes, though they are less productive, are important sources of genetic variability for breeding programs, which seek superior genetic constitutions and alleles for production under adverse biotic and abiotic conditions (Araújo and Nass, 2002).

The search for available, adapted maize germplasm and adequate selection for each growing environment, should take into account production potential (Albrecht et al., 2009), synergy of the genotype used, acclimatization to the factors of the environment, as well as growth and development relations of the plants (Bergamaschi and Matzenauer, 2009). Corn plants of a specific genotype follow a pattern regarding their development, interval between phases, final number of leaves and responses to the conditions of the growing environment (Ritchie et al., 1993). The productive potential is determined in specific phenological stages, and productivity is influenced directly by environmental stresses in these stages. In this sense the choice of genotypes more adapted to the conditions of the environment is important in order to increase the yield of maize. In order to obtain more productive genotypes, it is necessary to search for greater genetic variability in the characters of interest (Szareski et al., 2018); in this way, the use of open pollinated varieties is useful to address the needs for crop improvement. The objective of this work was to characterize the corn genotypes in a multivariate manner and to examined the canonical interrelations between characters of agronomic importance that influence the productive performance of the crop. 


\section{MATERIAL AND METHODS}

This work was carried out in the agricultural harvest of 2016/2017 in Entre-Ijuís - RS, located in the Northwest Region of Rio Grande do Sul, Brazil. This environment has an altitude of 215 meters, Latitude $28^{\circ} 21$ ' 32 "S and Longitude $54^{\circ} 16^{\prime} 04^{\prime \prime} \mathrm{W}$. The climate is humid subtropical of the Cfa type according to the classification of Köppen and the annual precipitation is approximately $2000 \mathrm{~mm}$. The soil is characterized as Typic Red Latosol (Streck et al., 2008). During the experiment, the monthly maximum temperature and minimum of the air and rainfall, obtained by data from INMET (National Institute of Meteorology), were obtained (Figure 1).
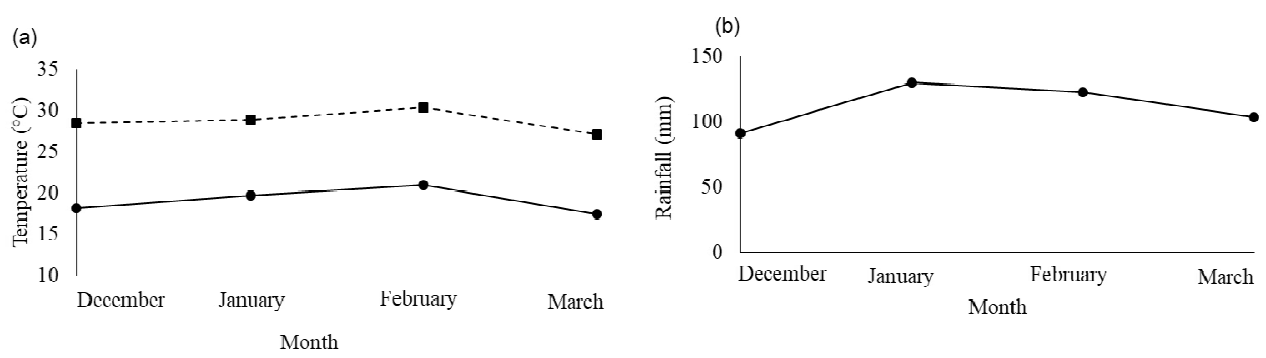

Figure 1. Monthly averages of maximum ( $---^{-}$) and minimum temperatures ( - ), (a) and precipitation (b) during the months of December 2016 to March 2017

Sowing was done in a previously fertilized area and soil acidity was corrected based on the soil analysis (Table 1). Spatial separation of genotypes was used to minimize crosspollination and varietal mixtures (Brasil, 2009).

Table 1. Acidity $(\mathrm{pH})$, phosphorus $(\mathrm{P})$, potassium $(\mathrm{K})$, sulfur $(\mathrm{S})$, calcium $(\mathrm{Ca})$, magnesium $(\mathrm{Mg})$, aluminum (Al), cation exchange capacity (CEC), organic matter (OM) and clay of soil in Entre-Ijuís - RS.

\begin{tabular}{|c|c|c|c|c|c|c|c|c|c|}
\hline & \multicolumn{5}{|c|}{ mg.dm $^{-3}$} & \multicolumn{2}{|c|}{$\mathrm{cmol}_{\mathrm{dm}} \mathrm{dm}^{-3}$} & \multicolumn{2}{|l|}{$\%$} \\
\hline $\mathrm{pH}_{(\mathrm{H} 20)}$ & $\mathrm{P}$ & $\mathrm{K}$ & $\mathrm{S}$ & $\mathrm{Ca}$ & $\mathrm{Mg}$ & $\mathrm{Al}$ & CEC & $\mathrm{OM}$ & Clay \\
\hline 6.0 & 4.7 & 147.5 & 18.9 & 6.1 & 2.7 & 0.0 & 12.0 & 2.6 & 68 \\
\hline
\end{tabular}

The treatments were composed of six open-pollinated corn genotypes (PL 712, PL 725, PL 796, PL 804 and PL 861) commonly used by family farmers of Ametista do Sul $\mathrm{RS}$, at the geographic coordinates $27^{\circ} 21^{\prime} \mathrm{S}$ and $53^{\circ} 10^{\prime} 54^{\prime \prime} \mathrm{W}$. All genotypes gave a minimum germination of $95 \%$, planted in a conventional sowing system, with a line spacing of 0.45 meters and a population density of 55,000 plants per hectare (Borghi and Crusciol, 2007). The experimental units were $16.20 \mathrm{~m}^{2}$, with a spacing of $4.5 \mathrm{~m}$. The following characters were measured in 10 random and homogeneous plants in the experimental unit:

- Plant height (PHE): measured by the distance between the soil level to the last fully expanded leaf, results in centimeters.

- Ear insertion height (EHE): distance between ground level and the insertion node of the first viable ear, results in centimeters. 
- Stem diameter (SDI): obtained with the aid of a digital caliper where the measurements were standardized, in the sense that the equipment is perpendicular to the sowing line, results in centimeters.

- Ear length (ELE): obtained through the extension between the basal and apical end of the ear, results in centimeters.

-Number of seed rows of the ear (NRE): obtained by counting the number of rows containing whole seeds per ear, results in units.

- Number of seeds per row of ear (NSR): measured by the magnitude of seeds arranged longitudinally in the row of the ear, results in units.

- Thousand seed weight (TSW): determined according to the Rules for Seed Analysis (Brasil, 2009), results in grams.

- Seed yield (YEI): obtained through the harvest and track of the useful area of each experimental unit, adjusted to $13 \%$ moisture and yield per hectare, in $\mathrm{kg} \cdot \mathrm{ha}^{-1}$.

- Germination test (GER): this was conducted through four samples containing four subsamples of 50 seeds. These were arranged to germinate in rolls formed by three sheets of Germitest ${ }^{\circledR}$ paper, moistened with distilled water 2.5 times the dry mass of the paper. Afterwards, the rolls were transferred to germination B.O.D. chamber type (Biochemical Oxygen Demand), with temperature and luminous period established by the legislation (Brasil, 2009). Results expressed as percentage of normal seedlings at seven days after the beginning of the tests.

- First germination count (FCG): this was performed four days after the beginning of the tests, results expressed as a percentage (Brasil, 2009).

- Emergence of seedlings in the field (EME): this was conducted through four subsamples containing 50 seeds each, at 12 days after the implantation the measurement of emergence of seedlings for all genotypes was carried out, results expressed as a percentage.

- Cold test (CTE): this was carried out through four replicates with 50 seeds per treatment, these being seeded in a roll of paper moistened with distilled water equivalent to 2.5 times the mass of the dry substrate. The rolls were placed in a cold chamber at $10^{\circ} \mathrm{C}$ where they remained for seven days (Barros et al., 1999); after this period, they were arranged in a germinator at $25^{\circ} \mathrm{C}$ for 5 days where the percentage of normal seedlings was obtained.

The experimental design was a randomized block with four replications. The data were submitted to the assumptions of the statistical model, where the normality and homogeneity of the residual variances were verified, as well as the additivity of the model, after which the analysis of variance at $5 \%$ of probability was performed by the $\mathrm{F}$ test in order to identify the presence of variability among genotypes. The characters that were significant were submitted to the complementary analyzes through the comparison of means by Tukey to $5 \%$ of probability. After all the significant characters were submitted to multivariate models where the matrix of genetic dissimilarity was made through the Mahalanobis algorithm, which served as the basis for elaborating the relative contribution of the characters by the method of Singh (1981), dendrogram that exposed the genetic distances tested and grouped by the UPGMA method and main components. Subsequently, the analysis of linear association was performed in order to verify the trend between the characters with significance based on $5 \%$ probability by the t-test, in order to determine the multivariate interrelationships the characters were subdivided into physiological group comprising: GER, FCG, EME and CTE, and group of morphological characters and yield 
which comprised: PHE, SDI, EHE, NRE, NSE, ELE, NSE, TSW and YEI. Subsequently, the phenotypic matrix was submitted to the multicollinearity diagnosis through the number of conditions (NC) of the matrix (Cruz et al., 2012). Then, the canonical correlation analysis was performed, where the significance between the groups of characters was obtained by the Likelihood Ratio Test (LRT) at 5\% probability.

\section{RESULTS AND DISCUSSION}

The analysis of variance revealed a significant difference at $5 \%$ of probability by the $F$ test for the attributes PHE, EHE, SDI, ELE, NRE, TSW, YEI, GER, FCG and CTE (Table 2).

Table 2. Summary of analysis of variance with mean squares and significance for agronomic and physiological characters of different corn genotypes.

\begin{tabular}{|c|c|c|c|c|c|c|c|c|}
\hline & \multirow{2}{*}{ D.F. } & \multicolumn{7}{|l|}{ Mean Square } \\
\hline & & PHE & SDI & EHE & NRE & NSR & ELE & NSE \\
\hline Genotype & 5 & $11231.64 *$ & $7.65^{*}$ & $3528.23 *$ & $29.98^{*}$ & $100.35^{*}$ & $13.35^{*}$ & 48161.98* \\
\hline Block & 19 & 17.85 & 0.33 & 16.19 & 4.81 & 6.21 & 3.71 & 5360.72 \\
\hline Residue & 95 & 22.01 & 0.64 & 14.33 & 2.69 & 4.59 & 5.17 & 3278.44 \\
\hline \multirow[t]{3}{*}{$\mathrm{CV}(\%)$} & - & 2.19 & 20.52 & 3.62 & 11.20 & 7.37 & 14.13 & 13.45 \\
\hline & \multirow{2}{*}{ D.F. } & Mean Square & \multirow{2}{*}{ D.F. } & Mean Square & & & & \\
\hline & & TSW & & YEI & GER & FCG & EME & CTE \\
\hline Genotype & 5 & $5785.92 *$ & 5 & $3923627.50 *$ & $0.0046^{*}$ & $0.0043^{*}$ & $0.0067 *$ & $0.01 *$ \\
\hline Block & 7 & 94.49 & 3 & 18348.61 & 0.00007 & 0.0003 & 0.0004 & 0.0005 \\
\hline Residue & 35 & 74.75 & 15 & 48211.94 & 0.0002 & 0.0003 & 0.0004 & 0.0003 \\
\hline $\mathrm{CV}(\%)$ & - & 3.60 & $\mathrm{CV}(\%)$ & 3.51 & 1.86 & 2.11 & 2.66 & 2.27 \\
\hline
\end{tabular}

* significant at 5\% probability, Degrees of freedom (DF), coefficient of variation (CV\%), germination (GER), first germination count (FCG), seedling emergence (EME), cold test (CTE), plant height (PHE), stem diameter (SDI), ear insertion height (EHE), number of seed rows (NRE), number of seeds per row (NSR), ear length (ELE), number of grains per ear (NSE), thousand seed weight (TSW) and seed yield (YEI).

PHE is highly influenced genetically and by the effects of the environment (Souza et al., 2003), plant population (Brachtvogel et al., 2012), and soil nutrient availability (Repke et al., 2013). Among the genotypes characterized, the highest PHE was obtained for PL 712 with $246.76 \mathrm{~cm}$ (Table 3), the EHE was $120.3 \mathrm{~cm}$ for the same genotype (Table 3). However, these variables obtained a minimum magnitude for PL 804 with $184.46 \mathrm{~cm}$ (PHE) and $90.95 \mathrm{~cm}$ (EHE). The PHE is an important characteristic for this cereal, mainly for the best balance of the plant (Kappes et al., 2013), being this attribute dependent of the plant population (Kappes et al., 2013), characteristics and genotype response to nutrient factors mainly from nitrogen (Santos et al., 2010) and potassium (Rodrigues et al., 2014).

The NRE revealed that PL 712 and PL 823 were higher and PL 796 and PL 804 were lower for this character (Table 3). This attribute is determined by the genetic constitution (Neto et al., 2003; Valderrama et al., 2011), environmental conditions (Carmo et al., 2012; Albuquerque et al., 2013) and attributes of the nutritional and water management established at vegetative stage V8 (Magalhães and Durães, 2006). For the magnitude of NSE, genotype PL 823 stood out (Table 3), and a similar tendency was found for the number of rows and seeds per row of the ear. 
Table 3. Means for plant height (PHE), stem diameter (SDI), ear insertion height (EHE), number of rows per ear (NRE), number of seeds per row (NSR), ear length (ELE) and number of seeds per ear (NSE), thousand seed weight (TSW), yield (YEI), germination (GER), first germination count (FCG), seedling emergence (EME) and cold test (CTE) of different corn genotypes.

\begin{tabular}{|c|c|c|c|c|c|c|c|c|c|c|c|c|c|}
\hline Genotypes & PHE & SDI & EHE & NRE & NSR & ELE & NSE & TSW & YEI & GER & FCG & EME & CTE \\
\hline PL 712 & $243.9 \mathrm{a}$ & $4.9 \mathrm{a}$ & $120.3 a$ & $16.5 \mathrm{a}$ & $27.1 d$ & $17.4 \mathrm{a}$ & $448.6 \mathrm{~b}$ & $287.85 a$ & $7250 \mathrm{a}$ & $94 a$ & $90 \mathrm{a}$ & $92 a$ & $81 \mathrm{ab}$ \\
\hline PL 725 & $200.2 \mathrm{c}$ & $3.7 \mathrm{bc}$ & $94.0 \mathrm{c}$ & $13.8 \mathrm{c}$ & $27.7 \mathrm{~cd}$ & $15.8 b$ & $380.9 \mathrm{c}$ & $242.6 b c$ & $6250 \mathrm{abc}$ & $76 \mathrm{bc}$ & $89 a$ & $85 \mathrm{ab}$ & $76 \mathrm{bc}$ \\
\hline PL 823 & $240.3 a$ & $3.4 \mathrm{c}$ & $112.6 \mathrm{~b}$ & $15.8 \mathrm{ab}$ & $32.4 \mathrm{a}$ & $17.4 \mathrm{a}$ & $513.0 \mathrm{a}$ & $271.5 \mathrm{ab}$ & $7120 \mathrm{ab}$ & $82 a$ & $90 \mathrm{a}$ & $85 \mathrm{ab}$ & $82 a$ \\
\hline PL 796 & $196.4 \mathrm{c}$ & $4.2 b$ & $93.5 \mathrm{c}$ & $13.7 \mathrm{c}$ & $29.4 \mathrm{bc}$ & $15.4 \mathrm{~b}$ & $402.4 b c$ & $226.6 b c$ & $5250 \mathrm{~cd}$ & $76 b c$ & $85 \mathrm{ab}$ & $85 \mathrm{ab}$ & $76 \mathrm{bc}$ \\
\hline PL 804 & $187.4 d$ & $3.3 \mathrm{c}$ & $90.9 \mathrm{c}$ & $13.6 \mathrm{c}$ & $30.8 \mathrm{ab}$ & $15.8 \mathrm{~b}$ & $418.7 b c$ & $226.3 \mathrm{~cd}$ & $5210 \mathrm{~d}$ & $72 \mathrm{c}$ & $80 \mathrm{~b}$ & $79 b$ & $72 \mathrm{c}$ \\
\hline PL 861 & $219.7 b$ & $3.6 \mathrm{bc}$ & $116.8 \mathrm{a}$ & $14.5 \mathrm{bc}$ & $26.8 \mathrm{~d}$ & $15.2 b$ & $389.7 \mathrm{c}$ & $205.2 \mathrm{~d}$ & $6210 \mathrm{bcd}$ & $81 \mathrm{ab}$ & $88 \mathrm{ab}$ & $79 b$ & $81 \mathrm{ab}$ \\
\hline CV (\%) & 2.1 & 19.8 & 3.6 & 11.5 & 7.5 & 10.1 & 13.7 & 2.84 & 3.51 & 2.27 & 2.11 & 2.66 & 2.27 \\
\hline
\end{tabular}

Means followed by the same lowercase letter in the column do not differ significantly from each other at $5 \%$ probability. $\mathrm{CV}: \mathrm{CV}=$ Coefficient of variation

The TSW and YEI presented differentials for the genotypes tested, with coefficients of variation of 3.84 and $3.51 \%$, respectively. The thousand seed weight is considered of great importance for seed productivity (Veloso et al., 2006), but it is dependent on nutrition (Castoldi et al., 2011), genetic characteristics and crop harvest (Schiavinatti et al., 2011). Physiologically this attribute is related to the magnitude of assimilates allocated in the seed during its development; a favorable growing environment without limitations can result in an increase of seed mass (Peske et al., 2012).

The genotype PL 712 was superior for the thousand seed weight; in contrast, the PL 861 genotype was $30 \%$ inferior to the best genotype studied. TheYEI determined that genotype PL 712 was higher at $7250 \mathrm{~kg} \cdot \mathrm{ha}^{-1}$. Studies by Mittelmann et al. (2005) demonstrated that this response to seed yield in maize genotypes with open pollination is due to the great genetic variability between genotypes and plants of the same genotype, environmental effects, agricultural harvest and interaction between these factors.

The GER showed that genotype PL 712 was superior with 94\% of germination (Table $3)$. It was also observed that all the genotypes tested were superior to the desirable $85 \%$ germination standards (Rocha et al., 2009). The FCG determined that genotypes PL 712, PL 823 and PL 725 expressed vigor greater than $89 \%$. The germination test contemplates seedling establishment estimates under optimum conditions, vigor tests are essential to determine the performance of seed lots on adverse environmental conditions (Bhering et al., 2003). According to Munizzi et al., (2010), seeds of higher physiological quality have high speed metabolic processes, rapid germination and seedling uniformity. Both the growing environment and the genotype used have important contribution to seed quality (Prazeres, 2014).

The EME in the field is influenced by seed vigor, and this attribute can be affected according to Silva et al., (2012), the quality of the corn seeds used, the environmental conditions of the production field, conditions of harvesting, drying, processing and storage. The genotype PL 712 presented greater field emergence with $92 \%$ vigor. These effects are attributed to the sum of the genetic, physical, physiological and sanitary attributes linked to the seeds used (Marcos Filho, 2005).

For the CTE superiority was conferred for genotype PL 712. The cold test has as basic principle the exposure of the seeds to adverse factors directed to low temperature. This condition reduces the probability of survival of the less vigorous seeds, since the low temperature contributes to reduce the speed of germination of the seeds (Barros et al., 1999). In this way, genotypes PL 823, PL 712 and PL 861 were higher (Table 3). 
In order to distinguish genetically the genotypes according to phenotypic measurements, the Singh Method (1981) was used, which is based on the premise of identifying which characters most contribute to the differentiation of genotypes. This included EHE $(10.12 \%)$, CTE $(9.41 \%)$, NRE (8.81\%), PHE $(8.75 \%)$ and TSW $(8.59 \%)$ as the most important and of high variability attributes, since they represented $45 \%$ of the total genetic variation among the genotypes. Minimum effects were obtained through EME (5.3\%) and GER (6.04) of the genotypes (Figure 2) studied.

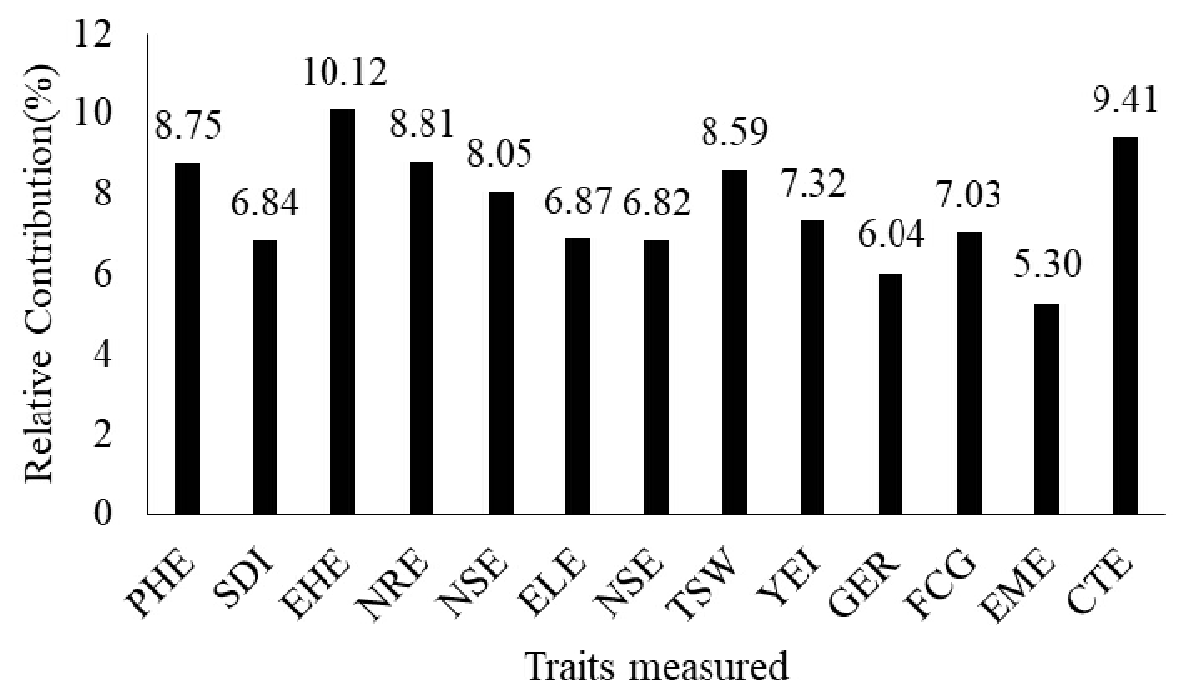

Figure 2. Relative contribution of the characters plant height (PHE), stem diameter (SDI), ear insertion height (EHE), number of rows per ear (NRE), number of seeds per row (NSR), ear length (ELE) and number of seeds per ear (NSE), thousand seed weight (TSW), yield (YEI), germination (GER), first germination count (FCG), seedling emergence (EME) and cold test CTE) for the dissimilarity among six corn genotypes, performed by the Singh (1981) method.

The genetic distance obtained by the Mahalanobis algorithm is obtained through the phenotypic information measured in genotype tested (Cruz et al., 2012). It is used as the basis for the genetic dissimilarity dendrogram, where PL725 and PL796 genotypes (Figure 3) were similar and PL804 genotype contrasted with the others for the characteristics studied.

The use of multivariate methods made it possible to differentiate the genotypes and to organize them into groups (Figure 4). In this way, genotypes PL 796, PL 725 and PL 861 formed Group 1 (Figure 4), however, the genotypes PL 804, PL 823 and PL 712 showed greater dissimilarity for the characteristics, culminating in the isolated allocation and their representation in Group 2, 3 and 4, respectively. In this sense, multivariate methods are promising and useful for grouping genotypes that express contrasting phenotypes, facilitates the interpretation of a wide range of data, optimizes trends and responses, and facilitates scientific decisions. 


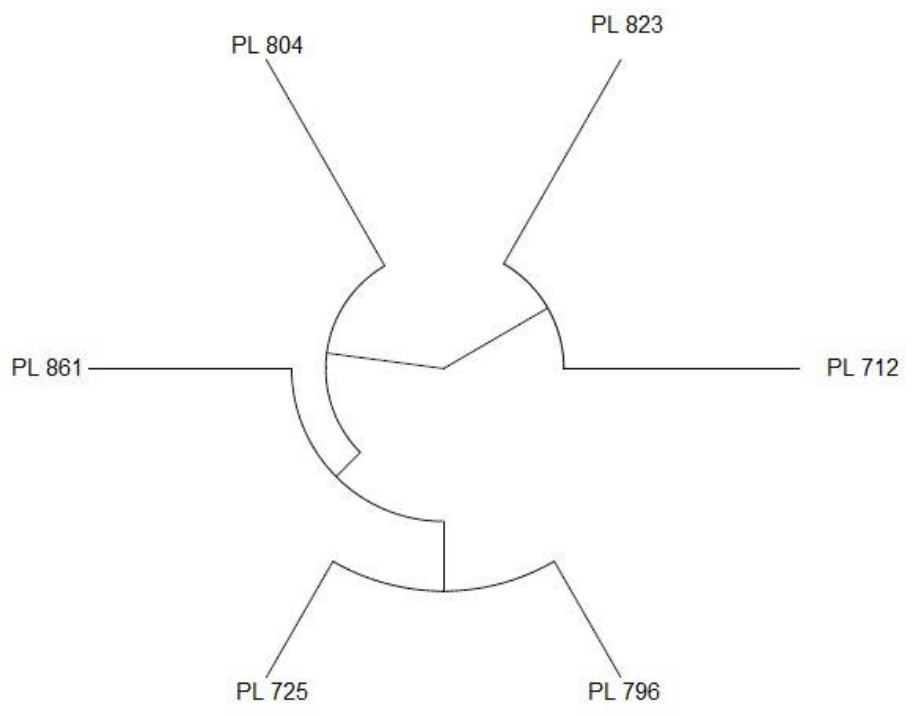

Figure 3. Dendrogram of genetic dissimilarity of six corn genotypes (PL 712, PL 725, PL 796, PL 804 and PL 861) using the Mahalanobis distance and UPGMA grouping method, obtained through the characters plant height (PHE), stem diameter (SDI), ear insertion height (EHE), number of rows per ear (NRE), number of seeds per row (NSR), ear length (ELE) and number of seeds per ear (NSE), thousand seed weight (TSW), yield (YEI), germination (GER), first germination count (FCG), seedling emergence (EME) and cold test (CTE).

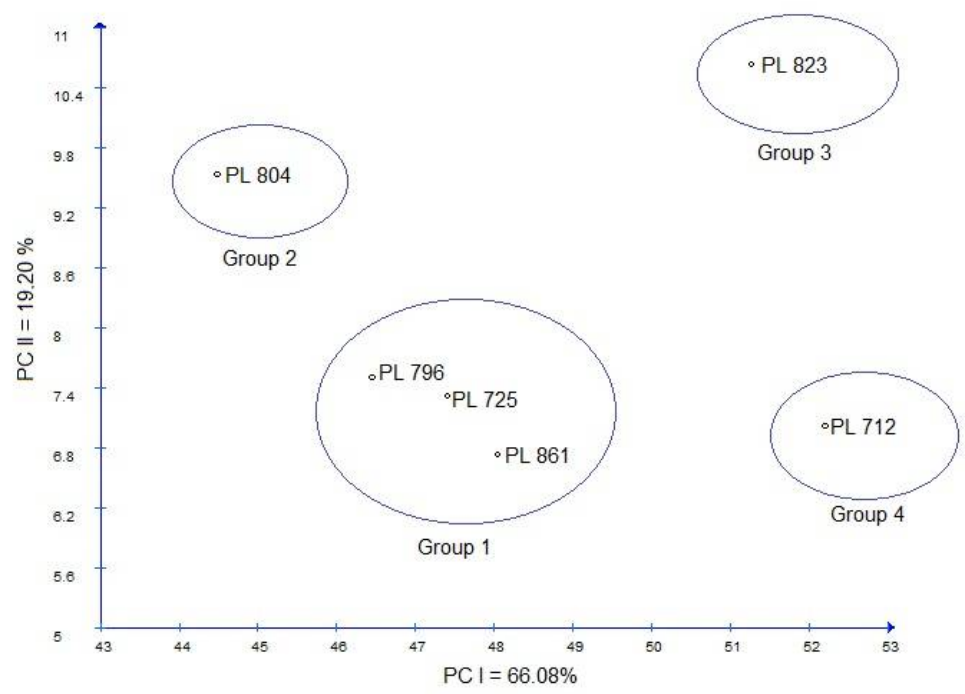

Figure 4. Principal components for the formation of groups for the six corn genotypes (PL 712, PL 725, PL 796, PL 804 and PL 861) obtained by analysis of the plant height characters (PHE), stem diameter (SDI), ear insertion height (EHE), number of rows per ear (NRE), number of seeds per row (NSR), ear length (ELE) and number of seeds per ear (NSE), thousand seed weight (TSW), yield (YEI), germination (GER), first germination count (FCG), seedling emergence (EME) and cold test (CTE). 
Estimates of the linear correlations were obtained for the PHE, SDI, EHE, NRE, NSR, ELE, NSE, TSW, YIE, GER, FGC, EME and CTE characters measured in five maize genotypes. There were 78 linear associations, where 57 associations were significant by the $\mathrm{t}$ test at $5 \%$ probability (Table 4 ). The positive and significant coefficients were obtained for PHE with SDI, EHE, ELE, NSE, TSW, YIE, GER, FCG, EME and CTE.

Table 4. Linear correlations between plant morphological characters and seed physiology analyzed in six corn genotypes (Zea mays). All correlations were significant at $5 \%$ probability by the test. Sample $\mathrm{N}$ $=120$.

\begin{tabular}{|c|c|c|c|c|c|c|c|c|c|c|c|}
\hline \multirow{10}{*}{ PHE } & SDI & 0.25 & \multirow{10}{*}{ EHE } & NRE & 0.46 & \multirow{8}{*}{ NRE } & ELE & 0.35 & \multirow{6}{*}{ ELE } & NSE & 0.42 \\
\hline & EHE & 0.90 & & NSR & -0.23 & & NSE & 0.79 & & YIE & 0.64 \\
\hline & ELE & 0.24 & & NSE & 0.25 & & TSW & 0.42 & & GER & 0.60 \\
\hline & NSE & 0.40 & & TSW & 0.32 & & YIE & 0.80 & & FGC & 0.58 \\
\hline & TSW & 0.62 & & YIE & 0.81 & & GER & 0.65 & & EME & 0.64 \\
\hline & YIE & 0.92 & & GER & 0.66 & & FGC & 0.62 & & CTE & 0.59 \\
\hline & GER & 0.77 & & FGC & 0.64 & & EME & 0.66 & \multirow{3}{*}{ NGR } & ELE & 0.25 \\
\hline & FGC & 0.75 & & EME & 0.52 & & CTE & 0.72 & & NSE & 0.57 \\
\hline & EME & 0.66 & & CTE & 0.87 & \multirow{5}{*}{ YIE } & GER & 0.86 & & FGC & 0.92 \\
\hline & CTE & 0.88 & & & & & FGC & 0.87 & GER & EME & 0.77 \\
\hline \multirow{5}{*}{ SDI } & EHE & 0.23 & & YIE & 0.74 & & EME & 0.74 & & CTE & 0.63 \\
\hline & NSR & -0.30 & & GER & 0.56 & & CTE & 0.77 & FGC & EME & 0.60 \\
\hline & TSW & 0.31 & TSW & FGC & 0.54 & & & & $\mathrm{FGC}$ & CTE & 0.64 \\
\hline & GER & 0.46 & & EME & 0.71 & \multirow{2}{*}{ NSE } & TSW & 0.43 & & & \\
\hline & EME & 0.51 & & CTE & 0.46 & & YIE & 0.52 & EME & CTE & 0.51 \\
\hline
\end{tabular}

Germination (GER), first germination count (FCG), seedling emergence (EME), cold test (CTE), plant height (PHE), stem diameter (SDI), ear insertion height (EHE), number of seed rows (NRE), number of seeds per row (NSR), ear length (ELE), number of grains per ear (NSE), thousand seed weight (TSW) and seed yield (YEI).

These linear associations have demonstrated that plants with larger stature increase the components of seed yield, such as the number of seeds per ear and the thousand seed weight. The attributes of the physiological quality of the seeds produced are positively affected by larger plants. The plant height can modify the arrangement of the ears and the equilibrium point of these in the plant, the dimensions and the mass of the ear are modified, making it beneficial to the seed yield.

The variable number of NRE correlated positively with NSE $(r=0.79)$, YEI $(r=$ $0.80)$ and CTE $(r=0.79)$. For genotypes with more rows of seeds in the ear may result in an increase in the magnitude of seeds per ear and yield, in addition, the thousand seed weight contributes to the physiological quality through the CTE. The physiological seed quality variables showed a significant correlation of the EME with GER, FCG and CTE, and it was possible to pre-establish the performance of the EME.

The canonical correlations were made between the physiological characters (group I), being: GER, FCG, EME and CTE, and secondary characters (group II) such as PHE, SDI, EHE, NRE, NSE, ELE, NSE, TSW and YEI. Considering the obtained results a canonical pair was significant $(\mathrm{P}<0.0001)$. The canonical pair showed inter-class correlation of $\mathrm{r}=0.97$, which corresponds to a high intergroup correlation coefficient, which shows a high dependence among the groups of characters studied (Carvalho et al., 2015). The canonical interrelations define that the germination, first count of germination, emergence of field seedlings and cold test (physiological group) were favored by the increase of plant height, height of ear insertion, number of rows of the ear and seed yield, however, the number of seeds per row of ear has disadvantaged the physiological potential. 
The genotypes of corn with plants of higher stature can show superior competitive ability, this allows to intercept more efficiently the photosynthetically active energy. Because these plants have high leaf area, they supply the need of assimilates and are more efficient in the formation of seeds of higher physiological quality (De Souza et al., 2015).

Table 5. Canonical loads for the characters of physiological quality (physiological group) and morphological/yield characters (morphological/yield group) in the canonical correlations (r) between groups for the six corn genotypes.

\begin{tabular}{lc}
\hline Character & Canonical pair \\
\hline Physiological group & \\
\hline GER $^{1}$ & 0.87 \\
FGC & 0.85 \\
EME & 0.74 \\
CTE & 0.86 \\
\hline Morphological/Yield Group & \\
\hline PHE & 0.91 \\
SDI & 0.36 \\
EHE & 0.83 \\
NRE & 0.78 \\
NSR & -0.18 \\
ELE & 0.69 \\
NSE & 0.50 \\
TSW & 0.63 \\
YEI & 0.92 \\
\hline r & 0.97 \\
(LRT) P & 0.0001 \\
P: probability (Likelihood Ratio Test), r: Canonical correlation interclass, 1 (physiological group) germination (GER), \\
first germination count (FCG), seedling emergence (EME) and cold test (CTE). 2 (Morphological group) plant height \\
(PHE), stem diameter (SDI), ear insertion height (EHE), number of seed rows (NRE), number of seeds per row (NSR), \\
ear length (ELE), number of grains per ear (NSE), thousand seed weight (TSW) and seed yield (YEI).
\end{tabular}

In view of the results, it was possible to identify the most productive genotypes, such as PL 712, PL 823 and PL 725, which also showed superiority to the physiological quality of the seeds produced. In this context, it was identified that the EHE, CTE, NRE, PHE and TGW characters presented greater genetic variability. The phenotypic linear associations between the genotypes were pronounceable among the characters of interest, and the canonical interrelations established for the physiological characters of the seeds and morphological / yield could help the future strategies of selection of corn genotypes, with the aim of greater productivity and physiological quality of the seeds produced.

\section{CONCLUSIONS}

Genetic variability makes it possible to cast genotype PL 712 as superior in seed productivity. The physiological quality of the seeds produced was variable among the genotypes, but it followed the trend of superiority for PL 712. Linear associations revealed the tendency of tall stature plants to increase the seed yield of the open pollinated corn variety. The most polymorphic characters were plant height and ear insertion, response to cold test, and thousand seed weight. The physiological attributes of the seeds produced are determined by the plant height, number of seed rows of the ear and seed yield. The trends obtained in this study allow us to guide future research with open pollinated varieties that 
advocate the selection and development of superior genotypes for the productivity and quality of the seeds produced in the extreme south of Brazil.

\section{REFERENCES}

Albrecht LP, Braccini AL, Ávila MR, Scapim CA, et al. (2009). Sementes de soja produzidas em época de safrinha na região oeste do estado do Paraná. Acta. Sci. Agron. 31: 121-127.

Albuquerque AW, Santos JR, Filho G and Reis LS (2013). Plantas de cobertura e adubação nitrogenada na produção de milho em sistema de plantio direto. Rer. Bras. Eng. Agr. Ambient. 17: 721-726.

Araújo PM and Nass LL (2002). Caracterização e avaliação de populações de milho crioulo. Sci. Ag. 59: 589-593.

Barros ASR, Dias MCLL, Cicero SM and Krzyzanowski FC (1999). Testes de frio. In: Vigor de sementes: conceitos e testes (Krzyzanowski FC, Vieira RD, França Neto JB, eds.). Abrates, Londrina.

Bergamaschi H and Matzenauer R (2009). Agrometeorologia do milho. In: Agrometeorologia dos cultivos: fator meteorológico na produção agrícola (Monteiro JE, ed.). INMET, Brasília.

Bhering MC, Dias DCFS, Barros DI, Dias LAS, et al. (2003). Avaliação do vigor de sementes de melancia (Citrullus lunatus Schrad.) pelo teste de envelhecimento acelerado. Rev. Bras. Sementes. 125: 1-6.

Borghi E and Crusciol CAC (2007). Produtividade de milho, espaçamento e modalidade de consorciação com Brachiaria brizantha no SPD. Pesq. Agropec. Bras. 42: 163-171.

Brachtvogel ELB, Pereira FRS, Cruz SCS, Abreu MLA, et al. (2012). População, arranjo de plantas uniforme e a competição intraespecífica em milho. R. Trop. Ci. Agr. Biol. 6: 75-83.

Brasil (2009). Ministério da Agricultura, Pecuária e Abastecimento. Guia de inspeção de campos para produção de sementes. 3 ed. Mapa/ACS, Brasília.

Carmo MS Do, Cruz SCS, Souza EJ de, Campos LFC, et al. (2012). Doses e fontes de nitrogênio no desenvolvimento e produtividade da cultura de milho doce (Zea mays convar. saccharata var. rugosa). Biosci. J. 28: 223-231.

Carvalho IR, Souza VQ, Nardino M, Follmann DN, et al. (2015). Canonical correlations between morphological traits and yield components in dual-purpose wheat. Pesq. Agropec. Bras. 12: 690-697.

Castoldi G, Costa SSM, Costa LM, Pivetta LA, et al. (2011). Sistemas de cultivo e uso de diferentes adubos na produção de silagem e grãos de milho. Acta. Sci. Agron. 33: 139-146.

Conab - Companhia Nacional de Abastecimento (2017). Acompanhamento da safra brasileira de grãos. Conab, Brasília.

Cruz CD, Regazzi AJ and Carneiro PCS (2012). Modelos biométricos aplicados ao melhoramento genético. 4 ed. Editora UFV, Viçosa.

De Souza VQ, Carvalho IR, Follmann DN, Nardino M, et al. (2015). Desfolhamento artificial e seus efeitos nos caracteres morfológicos e produtivos em híbridos de milho. Rev. Bras. Milho. Sorgo. 14: 61-74.

Ferreira Junior RA, Souza JL De, Teodoro I, Lyra GB, et al. (2014). Eficiência do uso da radiação em cultivos de milho em Alagoas. Rev. Bras. Eng. Agr. Ambient. 18: 322-328.

Kappes C, Arf O and Andrade JAC (2013). Produtividade do milho em condições de diferentes manejos do solo e de doses de nitrogênio. Rev. Bras. Cien. Solo. 37: 1310-1321.

Magalhães PC and Durães FOM (2006). Fisiologia da produção de milho. 1 ed. EMBRAPA-CNPMS, Sete Lagoas.

Marchi SL (2008). Interação entre desfolha e população de plantas na cultura do milho na Região Oeste do Paraná. Dissertação de Mestrado. Universidade Estadual do Oeste do Paraná, Marechal Cândido Rondon.

Marcos Filho J (2005). Fisiologia de sementes de plantas cultivadas. FEALQ, Piracicaba.

Mittelmann A, Sobrinho FS, Oliveira JS and Fernandes SBV (2005). Avaliação de híbridos comerciais de milho para utilização como silagem na região sul do Brasil. Cienc. Rural. 35: 684-690.

Morris M, Mekuria M and Gerpacio R (2003). Impacts of CIMMYT maize breeding research. In: Crop variety improvement and its effect on productivity: The impact of international agricultural research (Evenson RE, Gullin D, eds.). Cabi publishing: United Kingdom.

Munizzi A, Braccini AL, Rangel MAS, Scapim CA, et al. (2010). Qualidade de sementes de quatro cultivares de soja, colhidas em dois locais no estado de Mato Grosso do Sul. Rev. Bras. Sementes. 32: 176-185.

Neto DD, Palhares M, Vieira PA, Monfron PA, et al. (2003). Efeito da população de plantas e do espaçamento sobre a produtividade de milho. Rev. Bras. Milho. Sorgo. 2: 63-77.

Peske ST, Villela FA and Meneghello GE (2012). Sementes: Fundamentos Científicos e Tecnológicos. 3 ed. Editora Universitária/UFPel, Pelotas.

Pipolo VC, Souza A, Silva DD, Barrero TP, et al. (2010). Avaliação de cultivares de milho crioulo em sistema de baixo nível tecnológico. Acta Sci. Agron. 32: 229-233.

Prazeres CS (2014). Ganho genético para qualidade fisiológica em sementes de milho híbrido. Dissertação de Mestrado. Universidade do Estado de Santa Catarina, Lages.

Repke RA, Cruz SJS, Silva CJ, Figueiredo PG, et al. (2013). Eficiência da Azospirillum brasilense combinada com doses de nitrogênio no desenvolvimento de plantas de milho. Rev. Bras. Milho. Sorgo. 12: 214-226. 
Ritchie SW, Hanway JJ and Benson GO (1993). How a corn plant develops. Iowa State University of Science and Technology, Ames.

Rocha GP, Silva NC, Dourado ER, Teixeira MS, et al. (2009). Qualidade fisiológica de sementes de milho (Zea mays) e Sorgo (Sorghum bicolor) crioulos produzidas nos campos de sementes de agricultores (as) familiares de Porteirinha, Norte de Minas Gerais. Rev. Bras. Agroeco. 4: 4497-4500.

Rodrigues MAC, Buzetti S, Filho MCMT, Garcia CMP, et al. (2014). Adubação com KCl revestido na cultura do milho no Cerrado. Rev. Bras. Eng. Agri. Amb. 18: 127-133.

Sangoi L, Ernani PR, Silva PRF Da, Horn D, et al. (2006). Desempenho agronômico de cultivares de milho em quatro sistemas de manejo. Rev. Bras. Milho. Sorgo. 5: 218-231.

Santos PA, Silva AF, Carvalho MAC and Caione G (2010). Adubos verdes e adubação nitrogenada em cobertura no cultivo do milho. Rev. Bras. Milho. Sorgo. 9: 123-134.

Schiavinatti AF, Andreotti M, Benett CGS, Pariz CM, et al. (2011). Influência de fontes e modos de aplicação de nitrogênio nos componentes da produção e produtividade do milho irrigado no cerrado. Bragantia. 70: 925-930.

Silva AL da, Silva JF da, Almeida F de AC, Gomes JP, et al. (2012). Qualidade fisiológica e controle de sementes de milho tratadas com Piper nigrum. Rev. Bras. Prod. Agroind. 14: 131-142.

Singh D (1981). The relative importance of characters affecting genetic divergence. Indian. J. Genet. Pl. Br. 41: 237245.

Souza AB, Andrade MJB and Muniz JA (2003). Altura de planta e componentes de rendimento do feijoeiro em função da população de plantas, adubação e calagem. Cienc. Agrotec. 27: 1205-1213.

Streck EV, Kämpf N, Dalmolin RSD, Klamt E, et al. (2008). Solos do Rio Grande do Sul. 2 ed. EMATER/RS, Porto Alegre.

Szareski VJ, Carvalho IR, Kelh K, Pelegrin AJ, et al. (2018). Interrelations of characters and multivariate analysis in corn. J. Agric. Sci. 10: 187-194.

Valderrama M, Buzetti S, Benett CGS and Filho MCMT (2011). Fontes e doses de NPK em milho irrigado sob plantio direto. Pesq. Agropec. Trop. 41: 254-263.

Veloso MEC, Duarte SN, Neto DD and Miranda JH (2006). Doses de nitrogênio na cultura do milho, em solos de várzea, sob sistema de drenagem subterrânea. Rev. Bras. Milho. Sorgo. 5: 382-394. 